\title{
CORRIGENDUM
}

\section{Complex regulation of human androgen receptor expression by Wnt signaling in prostate cancer cells}

X Yang, M-W Chen, S Terry, F Vacherot, DL Bemis, J Capodice, J Kitajewski, A de la Taille, MC Benson, Y Guo and R Buttyan

Oncogene (2006) 25, 4256. doi:10.1038/sj.onc. 1209730

Correction to: Oncogene 2006; 25: 3436-3444. doi:10.1038/sj.onc.1209366; Published online 13 February 2006

A mistake occurred during the labeling of the gels, which resulted in some control bands being repeatedly

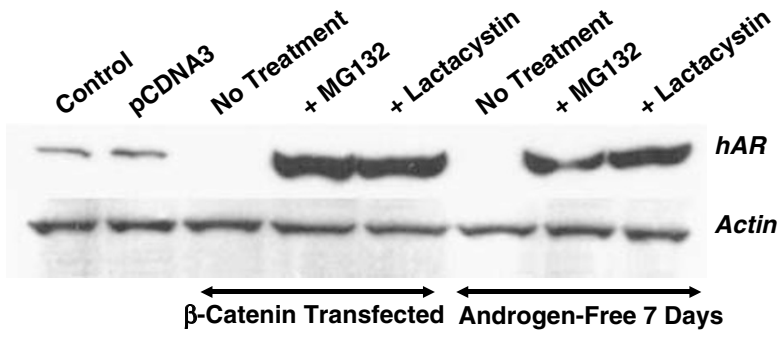

Figure 3 used in several figures. For this reason, some experiments have been performed again and Figures $3 \mathrm{c}$ and $4 \mathrm{a}$ have been replaced.

\section{ERRATUM}

\section{Gene expression profiling identifies molecular subtypes of gliomas}

\author{
R Shai, T Shi, TJ Kremen, S Horvath, LM Liau, TF Cloughesy, PS Mischel and SF Nelson
}

Oncogene (2006) 25, 4256. doi:10.1038/sj.onc.1209746

Correction to: Oncogene 2003 22: 4918-4923. doi:10.1038/sj.onc. 1206753

Due to a typesetting error, on page 4920 the Supplementary Information was referred to as 'Supplementary Figure x'. It should have read, 'Supplementary Table 3'.

The authors have provided this information on a publicly accessible website http://genomics.ctrl.ucla.edu/ snelson/PublicDATASETS/ Shai_Oncogene_2003/

where they have also placed all of the complete genomic information.

Correspondence to SF Nelson, E-mail: snelson@ucla. edu 